\title{
SISTEM EKONOMI ISLAM MENURUT PARA AHLI
}

\author{
Nuruddin Armantoa, \\ Nurul Fadilab \\ a,b Fakultas Ekonomi dan Bisnis Islam, Universitas Islam Zainul \\ Hasan Genggong Probolinggo \\ Email: nuruddinarmanto10@gmail.com
}

\begin{abstract}
Islamic economy is essentially a part of the interaction system in an effort to allocate resources with the aim of welfare and improving the standard of human life which is of course based on Islamic values in it. The emergence of history related to economics in Islam does not need to start from a discussion about economics that is connected with the Al-Quran and Sunnah. But basically the views regarding economic issues relate to the companions of the Prophet and the generation who followed them. Not a few of them are part of legal experts who come from Eminence.

What are the opinions or thoughts of historians about Islamic economics in which they discuss every concept of economic history of Ibn Hazm, Nizam al Mulk and Al Syatibi?
\end{abstract}

Kata kunci : Sistem Ekonomi dan Para Ahli

\section{PENDAHULUAN}

Ekonomi Islam hakikatnya merupakan bagian dari sistem interaksi dalam upaya alokasi sumber daya dengan tujuan untuk kesejahteraan dan meningkatkan taraf hidup manusia yang 
tentunya berlandaskan nilai - nila islam di dalamnya. Munculnya sejarah terkait ekonomi dalam islam tidak perlu dimulai dari adanya diskusi tentang ekonomi yang dihubungkan dengan $\mathrm{Al}$ Qur'an dan Sunnah. Namun pada dasarnya pandangan terkait isu - isu ekonomi berkaitan dengan para sahabat Nabi dan generasi yang mengikuti mereka. Tidak sedikit dari mereka merupakan bagian dari ahli hukum yang berasal dari Eminensia. Adanya penerapan ekonomi yang berlangsung sejak saat itu merupakan proses dari pengembangan yang dilakukan para ahli dalam menjalankan sistem perekonomian di setiap wilayah.

Keutamaan dari setiap tugas yang dijalankan diperlukan adanya bentuk pemikiran Islam terkait dengan perubahan ekonomi di berbagai wilayah dari seluruh dunia Islam. Setiap perkembangan ekonomi islam yang ada di setiap wilayah tentunya memiliki presepsi atau konsep sendiri - sendiri hal ini tentunya perlu adanya acuan pokok disesuaikan dengan perkembangan jaman yang sedang berlangsung. Sehingga dalam jurnal ini dijelaskan beberapa bentuk pemikiran sejarah tentang ekonomi Islam yang mana ddidalamnya membahas setiap konsep sejarah ekonomi Ibnu Hazm, Nizam al Mulk dan Al Syatibi.

\section{Pembahasan Masalah Pemikiran Ekonomi Menurut Ibnu}

\section{Hazm}

Beberapa pemikirannya yang terkenal dalam bidang Ekonomi antara lain:

Masalah sewa tanah dan kaitannya dengan pemerataan kesempatan. 
Sejalan dengan pendekatan zahirinya, Ibnu Hazm mengemukakan konsep pemerataan kesempatan berusaha dalam istinbat hukumnya di bidang ekonomi, sehingga cenderung kepada prinsip-prinsip ekonomi sosial Islami yang mengarah kepada kesejahteraan masyarakat banyak dan berlandaskan keadilan sosial dan keseimbangan sesuai dengan petunjuk Alqur'an dan Hadits. Oleh karena itu, sebagian penulis kontemporer menyatakan sebagai perintis ekonomi sosialis yang Islami. namun demikian, penilaian tersebut terlalu berlebihan dan cenderung menarik-narik syariat Islam kepada suatu sistem ekonomi kontemporer produk pemikiran Barat.

Syariat Islam bukan merupakan sistem sosialis yang menekankan kepemilikan kolektif sebagaimana pula bukan pemikiran kaum kapitalis yang menekankan kepada kepemilikan individual. Diantara pernyataan Ibnu Hazm berkenaan dengan sewa tanah adalah :"Menyewakan tanah sama sekali tidak diperbolehkan, baik untuk bercocok tanam, perkebunan, mendirikan bangunan, ataupun segala sesuatu, baik untuk jangka pendek, jangka panjang, maupun tanpa batas waktu tertentu, baik dengan imbalan dinar maupun dirham. Bila hal ini terjadi, hukum sewa-menyewa batal selamanya."

Selanjutnya, Ibnu Hazm menyatakan : "Dalam persoalan tanah, tidak boleh dilakukan kecuali muzara'ah (penggarapan tanah) dengan sistem bagi hasil produksinya atau mugharasah (kerjasama penanaman). Jika terdapat bangunan pada tanah itu, banyak atau sedikit, bangunan itu boleh disewakan dan tanah itu ikut pada bangunan tetapi tidak masuk dalam penyewaan sama 
sekali." Dengan pernyataan tersebut, Ibnu Hazm memberikan tiga alternatif penggunaan tanah, yaitu:

1) Tanah dikerjakan atau digarap oleh pemiliknya sendiri,

2) Si pemilik mengizinkan orang lain menggarap tanah tanpa sewa.

3) Si pemilik memberikan kesempatan orang lain untuk menggarapnya dengan bibit, alat, atau tenaga kerja yang berasal dari dirinya, kemudian si pemilik memperoleh bagian dari hasilnya dengan persentasi tertentu sesuai kesepakatan.

Hal ini sebagaimana telah dilakukan oleh Rasulullah Saw. dengan kaum Yahudi terhadap tanah Khaibar. Dalam sistem ini, jika tanaman itu gagal, si penggarap tidak dibebani tanggung jawab tertentu. Pandangan tersebut didasari pemahaman zahiriyahnya sebagai berikut: Dari Rafi' bin Khudaij r.a., ia berkata: "Rasulullah Saw melarang penyewaan tanah" (Riwayat Bukhari).

Dari Jabir bin Abdillah r.a., ia berkata: "Rasulullah Saw melarang pengambilan upah atau bagian tertentu dari tanah". (Riwayat Muslim) Dari Abu Hurairah r.a., ia berkata: "Rasulullah Saw bersabda: "Barang siapa memiliki tanah, hendaklah ia menanaminya atau memberikannya kepada saudaranya. Jika ia menolak, tahanlah tanah tersebut". (Riwayat Muslim) Pandangan Ibnu Hazm bertitik tolak dari status tanah sebagai barang yang tidak hancur (sil'ah ghair istikhlakiyyat) yang pada umumnya peran hasil kerja dan kreasi manusia tidak menonjol. Yang tampak ialah bahwa tanah itu merupakan ciptaan Allah Swt 
dimana manusia tinggal memanfaatkannya dan mengklaim pemilikan dan penguasaannya.

Dengan demikian, kepemilikan tersebut tidak mutlak, tetapi justru relatif selama ia memanfaatkannya. Jika tidak memanfaatkannya, ia harus memberikan kesempatan kepada orang lain untuk memanfaatkannya sesuai dengan asas kepemilikan umum tanah sebagai ciptaan Allah Swt. Oleh karena itu, menurut Ibnu Hazm, tanah tidak bisa disamakan dengan rumah atau peralatan yang secara nyata merupakan hasil kerja dan jerih payah manusia untuk membuatnya sehingga dapat disewakan.

a. Jaminan sosial bagi orang tak mampu

1) Pemenuhan kebutuhan pokok (Basic Needs) dan pengentasan kemiskinan Ibnu Hazm menyebutkan empat pokok yang memenuhi standar kehidupan manusia, yaitu: makanan, minuman, pakaian, dan perlindungan (rumah). Makanan dan minuman harus dapat memenuhi kesehatan dan energi. Pakaian harus dapat menutupi aurat dan melindungi seseorang dari udara panas dan dingin serta hujan. Rumah harus dapat melindungi seseorang dari berbagai cuaca dan juga memberikan tingkat kehidupan pribadi yang layak. Ibnu Hazm mengingatkan bahwa kemiskinan selalu tumbuh dalam situasi tingkat konsumsi atau kebutuhan lebih tinggi daripada pendapatan yang dapat memenuhi kebutuhan, karena terjadi populasi yang meningkat cepat (akibat kelahiran dan migrasi). 
Kesenjangan yang lebar antara si kaya dengan si miskin dapat menambah kesulitan saat keadaan orang kaya mempengaruhi struktur administrasi, cita rasa dan berbagai pengaruh lain, seperti kenaikan tingkat harga dalam aktivitas ekonomi.

Berkenaan dengan harta yang wajib dikeluarkan zakatnya, Ibnu Hazm memperluas jangkauan dan ruang lingkup kewajiban sosial lain di luar zakat, yang wajib dipenuhi oleh orang kaya sebagai bentuk kepedulian tanggung jawab sosial mereka terhadap orang miskin, anak yatim, dan orang yang tidak mampu atau yang lemah secara ekonomi. Salah satu pandangan Ibnu Hazm yang menarik dalam masalah ini adalah sebagai berikut[10] :"Orang-orang kaya dari penduduk setiap negeri wajib menanggung kehidupan orang-orang fakir miskin diantara mereka. Pemerintah harus memaksakan hal ini terhadap mereka jika zakat dan harta kaum muslimin (bait almal) tidak cukup untuk mengatasinya. Orang fakir miskin itu harus diberi makanan dari bahan makanan semestinya, pakaian untuk musim dingin dan musim panas yang layak, dan tempat tinggal yang dapat melindungi mereka dari hujan, panas matahari,dan pandangan orang-orang yang lalu lalang."Ibnu

2) Kewajiban mengeluarkan harta selain zakat. Mengenai adanya kewajiban harta selain zakat merupakan persoalan yang diperselisihkan oleh 
fuqaha. Sebagian fuqaha menyatakan keberadaan kewajiban harta yang harus dikeluarkan selain zakat. Pendapat ini dikemukakan oleh banyak sahabat dan tabi'in, dan bukan merupakan sesuatu yang baru dalam fiqih Islam dan Ibnu Hazm bukan orang pertama yang berpendapat demikian. Sebagian fuqaha lain menyatakan tidak ada kewajiban harta selain zakat. Harta yang dikeluarkan selain zakat merupakan sedekah atau santunan yang disunnahkan. Pendapat kedua ini masyhur dikalangan ulama fuqaha mutaakhirin, sehingga nyaris tidak dilenal pendapat yang lain. Dalil yang dikemukakan oleh hadits yang diriwayatkan oleh Bukhari, Muslim, dan lainnya dari sahabat Thalhah r.a., ia berkata :"Seorang sahabat laki-laki dari penduduk Najd dengan rambut tergerai datang mengadap Rosulullah saw. Suaranya terdengar parau dan apa yang dikatakan tidak mudah ditangkap.

Setelah mendekati Rosulullah saw, ia bertanya tentang islam. Kemudian Rosulullah saw menjawab "lima kali shalat dalam sehari semalam". Ia bertanya, “Apakah selain itu ada yang wajib bagi diriku?" Rasul menjawab, "Tidak, kecuali kamu shalat sunnah." Rasul berkata, "Dan berpuasa Ramadhan”. Ia bertanya, "Apakah ada puasa yang lain yang wajib bagi diriku?" Rasul menjawab, Tidak, kecuali kamu berpuasa sunnah". Kemudian Rasul menyebutkan zakat. Ia bertanya, "Apakah ada kewajiban selain 
zakat?" Rasul menjawab, “Tidak, kecuali kamu bersedekah sunnah". Lantas laki-laki itu berbalik seraya berkata, "Aku tudak akan menambahi ataupun menguranginya". Rasulullah Saw bersabda, "Dia beruntung jika jujur" atau "Dia masuk surga jika jujur”.

Hadits di atas menegaskan tidak ada kewajiban harta selain zakat, akan tetapi sebenarnya harus dipahami dalam konteks kewajibannya sama persis dengan zakat, yakni sebagai suatu kewajiban harta yang bersifat periodik, penyebab kewajibannya melekat pada jenis dan jumlah harta itu sendiri dengan ketentuan nisab dan kadar jumlah tertentu, tanpa memandang kondisi orang-orang yang berhak menerimanya. Ini merupakan bentuk fardhu ain yang wajib dipenuhi oleh seseorang yang memilki harta tertentu yang mencapai satu nisab, meskipun tidak ada fakir miskin. Dalam kondisi normal, ia tidak dituntut lebih daripada itu. Sebenarnya perbedaan dari kedua pendapat tersebut tidak bertolak belakang sama sekali. Kelompok pertama menyatakan sebagai kewajiban kifai, dan kelompok kedua memandangnya sebagai sesuatu yang sangat dianjurkan

b. Zakat

Ibnu Hazm menekankan pada status zakat sebagai suatu kewajiban dan juga menekankan peranan harta dalam upaya memberantas kemiskinan. Pemerintah sebagai 
pengumpul zakat dapat memberikan sanksi kepada orang yang tidak mau membayar zakat, sehingga orang mau mengeluarkan zakatnya, baik secara suka rela maupun terpaksa. Jika ada yang menolak zakat sebagai kewajiban, ia dianggap murtad. Dengan cara ini, hukuman dapat dijatuhkan pada orang yang menolak kewajiban zakat, baik secara tersembunyi maupun terang-terngan. Ibnu Hazm menekankan bahwa kewajiban zakat tidak akan hilang. Seseorang yang harus mengeluarkan zakat dan yang belum mengeluarkannya selama hayatnya harus dipenuhi kewajibannya itu dari hartanya, sebab tidak mengeluarkan zakat berarti hutang terhadap Allah SWT. Hal ini berbeda dengan pengeluaran pajak dalam pandangan konvensional yang jika tidak dibayarkan berarti kredit macet bagi negara dalam periode waktu tertentu. Sedangkan kewajiban zakat tidak dibatasi periode waktu tertentu.

c. Pajak

Ibnu Hazm sangat fokus terhadap faktor keadilan dalam sistem pajak, sebelum segala sesuatunya diatur, hasrat orang untuk mengeluarkan kewajiban pajak harus dipertimbangkan secara cermat karena apapun kebutuhan seseorang terhadap apa yang dikeluarkannya akan berpengaruh pada sistem dan jumlah pajak yang dikumpulkan. Hal ini mendiskusikan teori keuangan publik (public finance) konvensional berkaitan dengan kecenderungan orang untuk membayar pajak. Besarnya 
nilai pajak tanah umumnya adalah sebesar $1 / 6$ atau $1 / 3$ sesuai dengan kualitas tanah. Ibnu Hazm sangat memperhatikan sistem pengumpulan pajak secara alami. Dalam hal ini sikap kasar dan eksploitatif dalam pengumpulan pajak harus dihindari. Pengumpulan pajak juga tidak boleh melampui batas ketentuan syariah. Hilangnya para pembayar zakat berarti juga hilangnya eksistensi suatu negara. Hal ini mungkin terjadi karena hilangnya hasrat orang untuk membayar pajak sehingga mengurangi dukungan publik untuk tegaknya kekuasaan pemerintah dan menurunnya pendapatan pajak potensial juga mungkin muncul akibat terjadinya penyimpangan dan kecerobohan para petugas pajak. Penghimpunan administrasi pajak di Andalusia pada masa Ibnu Hazm dikemukakan oleh S.M. Imamuddin: "Cabang departemen keuangan terendah berada di pedesaan dan dikelola oleh seorang kepala devisi yang disebut amil. Saat hasil panen tiba, ladang diawasi dan hasil produksinya diperhitungkan oleh seorang petugas yang disebut ash-shar. Saat itu, ada mutaqabbil yang bertugas mengumpulakan pajak dan kewajiban lain berkaitan dengan fiskal di wilayahnya. Untuk mengawasi para petugas ini dari penipuan dan harga yang melebihi kewajiban dilakukan pengawasan ketat, sehingga hal ini dilakukan, mereka akan ditangkap”.

\section{Pemikiran Ekonomi Menurut Nizam Al Mulk}

Pemikiran Ekonomi Nizam Al-Mulk. Nizam Al-Mulk menyadari sepenuhnya mengenai 3 arah faktor-faktor 
kemakmuran, produktivitas dan efisiensi. Mengamankan kesejahteraan dapat meningkatkan lebih besar produktivitas yang diharapkan dan efisiensi. Ia mendemonstrasikan melalui kejadian terkait di bawah ini: Bahwa pada saat persoalan (affairs) Ray telah mengkhawatirkan Nizam al-Mulk, ia di beritahukan bahwa Quthlumus telah meninggalkan Fortress dari Kurd mulai Plundering negeri dan negeri Ray harus di serang, Alp Arslan juga mulai menuju Nishapur dan ia dengan tentaranya mencapai Damghan. Dengan rasa persaudaraan Alp Arslan mengirimkan sebuah pesan Quthlumus memintanya untuk kembali.

Namun Quthlumush memenuhi tidak menaruh perhatian dan mulai melakukan gangguan ke wilayah sekitar Ray. Quutlumush memenuhi lembaga al-Mith dengan air agar kiriman ke Ray tidak sampai. Situasi ini mengkhawatirkan Alp Arslan. Nizam al Mulk berkata kepadanya " sama sekali jangan khawatir, saya telah merekrut serdadu yang tembakannya tidak pernah mleset dar target. Saya telah mengamankan kesetiaan dari kitab suci Al Qur'an, ulama, dan sufi dari khurasan, kepadanya telah saya perlakukan dengan kasih sayang.

Mereka semua datang mendoakan untuk kemenangan Sultan. Tentara anda ini adalah pendukung anda yang paling baik". Setelah mengatakan ini, ia meletakkan senjata dan memberikan uang kepada bala tentara. Sultan membawa membagikan uang kepada bala tentara. Sultan membawa kudanya ke air dan menyebrangi dengan selamat beserta angkatan daratnya. Quthlumush terbunuh. Ketika Sultan kembali ke Ray pada tahun $456 \mathrm{H} / 1063 \mathrm{M}$, Admid al-Mulk menyambutnya 
dengan kehormatan militer penuh. Atas kemenangannya ini Alp Aslan sangat berterima kasih kepada Nizam al-Mulk. Memastikan bahwa kebutuhan pokok masyarakat dipenuhi secukupnya. Negara harus biasa menjamin ketersediaan pasokan yang cukup selama terjadi serangan hama atau gagal panen.

Nizam Al-Mulk menegaskan bahwa persamaan hak dalam kesempatan melakukan kegiatan ekonomi adalah persyaratan awal untuk mencapai persamaan sosial. Upaya ekonomi untuk mencapai tujuan ini mencakup manajemen zakat yang efektif, bangunan pondok dan rumah untuk rakyat miskin, dan tersedianya lapangan kerja bagi rakyat sesuai kapasitas dan imbalannya. Tentang pajak, Nizam Al-Mulk tidak menyangkal bahwa sistem pajak yang baik menjadi basis keuangan yang sehat. Walaupun demikian, ia percaya bahwa keuangan yang sehat bukanlah segala-galanya untuk menghindari kesulitan nasional.

Terkait dengan persoalan pajak tanah, Nizam Al-Mulk merekomendasikan pembatalan dari pembebanan (charge) oleh tuan tanah terhadap petani yang tidak dapat memenuhi kewajibannya membayar pajak. Dalam pandangannya, tuan tanah hanyalah sebatas pengumpul pajak, bahkan mereka tidak mempunyai hak untuk menetapkan jumlah pajak karena hal tersebut merupakan hak mutlak pemerintah. Dalam hal ini, Nizam Al-Mulk ingin mengurangi kekuasaan dan hak mutlak para tuan tanah, dan menjadikan pemerintah menjadi lebih berkuasa.

\section{Pemikiran Ekonomi Menurut Al Syatibi}

Al Syatibi merupakan salah satu tokoh pemikir islam yang lahir pada fase kedua sejarah perkembangan ekonomi Islam. Al 
Syatibi merupakan salah satu dari ahli hukum islam yang banyak menjelaskan tentang Maqasid Syariah yang merupakan kemaslahatan umat manusia yang menyangkut rejeki manusia, pemenuhan kebutuhan dan keinginan manusia. Jika berkaitan dengan Ekonomi Islam dalam menghidupkan ekonomi diperlukan adanya kerja keras para ekonom muslim untuk mencari nilai nilai yang terkandung dalam $\mathrm{Al}$ - Qur'an dan Sunnah yang terkait dengan masalah ekonomi yang kemudian dirumuskan dan dijadikan kaidah. Berikut pandangan Al Syatibi tentang bidang ekonomi.

a. Objek Kepemilikan

Pada dasarnya Al Syatibi mengakui adanya hak milik individu. Namun beliau, menolak adanya kepemilikan indvidu terkait dengan sumber daya yang dapat menguasai keperluan hidup orang banyak. Beliau menegaskan bahwa air bukanlah objek kepemililkan dan penggunaanya tida dapat dimiliki oleh siapapun. Dalam hal ini air dapat dibedakan menjadi dua macam yakni: air yang tidak dapat dijadikan sebagai objek kepemilikan seperti air sungai dan terdapat pula air yang dijadikan objek kepemilikan sperti air yang dibeli atau termasuk bagian dari sebidang tanah milik individu. Lebih jauh lagi, beliau menyatakan bahwa tidak ada hak kepemilikan yang dapat diakui terhadap sungai dikarenakan menggunakan adanya penggunaan dam. 
b. Pajak

Berkaitan dengan pajak al syatibi menjelaskan bahwa pemungutan pajak harus di lihat dari sudut pandang maslahah (kepentingan umum). Dengan mengutip adanya pendapat sebelumnyaAl Ghazali dan Ibnu Al Farra yang menyatakan bahwa pemeliharaan kepentingan umum secara dasar adalah tanggung jawab masyarakat. Dalam kondisi tidak mampu melaksanakan tanggung jawab tersebut, masyarakat dapat mengalihkan kepada Baitul Mall serta dapat menyumbankan sebagai kekayaan mereke sendiri untuk mencapai tujuan tersebut. Sehingga pemerintah dapat mengenakan pajak - pajak baru terhadap rakyatnya sekalipun pajak tersebut belum pernah dikenal dalam sejarah islam.

c. Kebutuhan dan Keinginan

Keinginan dalam ilmu ekonomi konvensional merupakan keinginan yang berasal dari naluriah manusia. Dalam ekonomi konvensional tidak adanya perbedaan antara keinginan dan kebutuhan karena keduanya sama sama memberikan efek yang sama bila tidak dipenuhi yaitu adanya kelangkaan. Disisi lain ekonomi Islam justru memerintahkan manusia agar meraih segala bentuk keinginan dan hasratnya. Ekonomi Islam memerintahkan individu untuk memenuhi kebutuhan seabgaimana yang dikehendaki secara syariat. Pada dasarnya kebutuhan juga berasal dari naluriah namun dari sudut pandang islam tidak semua keinginan naluriah itu dapat dijadikan sebagai 
kebutuhan, hanya keinginan yang mengandung mashalahah saja yang dapat dikategorikan sebagai kebutuhan.

\section{KESIMPULAN}

Adanya pemikiran tentang pelaksanaan ekonomi Islam di setiap penjuru dunia melalui beberapa point pokok dalam mengelola sistem ekonomi yang sedang berlangsung. Pada dasarnya ekonomi Islam merupakan bentuk bagian dari sistem interaksi dalam upaya alokasi sumber daya dengan tujuan untuk kesejahteraan dan meningkatkan taraf hidup manusia yang tentunya berlandaskan nilai - nila islam di dalamnya. Munculnya sejarah terkait ekonomi dalam Islam tidak perlu dimulai dari adanya diskusi tentang ekonomi yang dihubungkan dengan $\mathrm{Al}$ Qur'an dan Sunnah. Namun pada dasarnya pandangan terkait isu

- isu ekonomi berkaitan dengan para sahabat Nabi dan generasi yang mengikuti mereka. Terdapat 3 tokoh penting yang membahas tentang pelaksanaan ekonomi islam yakni Ibnu Hazm membahas tentang pelaksanaan sewa menyewa tanah, Jaminan sosial bagi orang tak mampu, zakat dan pajak, sedangkan Nizam al-Mulk membahas ekonomi islam berkaitan tentang kemakmuran, produktivitas dan efisiensi sedangkan Al Syatibi menjabarkan ekonomi islam terkait tentang objek kepemilikan, pajak serta kebutuhan dan keinginan. 


\section{DAFTAR PUSTAKA}

Ahmad al-Raisuni. 1995. Nazhariyah al - Maqashid 'Iinda al - Imam Al - Syatibi. Lebanon: Dar al Fikr as Islami.

Al - Qhardhawim Yusuf. 1993. Fiqh al - zakah. Beirut: Muassah al- Risalah

Asy- Syafara, Ismail. 2002. Ensikplopedi Filsafat. Jakarta: Khalifah

Chamid, Nur. 2010. Jejak Langkah Sejarah Pemikiran Ekonomi Islam. Kediri: Pustakan Pelajar

Ira M. Lapidus. 1999 Terjemahan Ghufron A. Mas'adi. A History of Islamic Societies, Terjemahan Sejarah Sosial Umat Islam. Jakarta: PT Raja Grafindo Peserda. 